\title{
I Kappa B
}

National Cancer Institute

\section{Source}

National Cancer Institute. I Kappa B. NCI Thesaurus. Code C17583.

\begin{abstract}
A family of proteins that bind to the nuclear localization signal (NLS) domains of the nuclear factor kappa-light-chain-enhancer of activated B cells (NF-kappaB) transcription factor complexes. This sequesters NF-kappaB in the cytoplasm and prevents its binding to the activation domains of target genes in the nucleus. Phosphorylation of I kappa B proteins, which is catalyzed by cytokine-activated I kappa B kinases (IKBK; IKK), disrupts binding to NF-kappaB and induces the degradation of I kappa B; this allows NF-kappaB to enter the nucleus and activate the transcription of target genes.
\end{abstract}

